University of Louisville

ThinkIR: The University of Louisville's Institutional Repository

Electronic Theses and Dissertations

6-1913

\title{
The religious element in the popular ballads.
}

Elizabeth Phillips McConathy

University of Louisville

Follow this and additional works at: https://ir.library.louisville.edu/etd

\section{Recommended Citation}

McConathy, Elizabeth Phillips, "The religious element in the popular ballads." (1913). Electronic Theses and Dissertations. Paper 938.

https://doi.org/10.18297/etd/938

This Master's Thesis is brought to you for free and open access by ThinkIR: The University of Louisville's Institutional Repository. It has been accepted for inclusion in Electronic Theses and Dissertations by an authorized administrator of ThinkIR: The University of Louisville's Institutional Repository. This title appears here courtesy of the author, who has retained all other copyrights. For more information, please contact thinkir@louisville.edu. 
TH $\mathrm{H}$ RI I G I O US EIEH EN T I IN $\mathrm{IH} \mathrm{P}$

P P J U I $A R$ B.A I I A D S

By

Elizabeth phillips lic conathy

Submitted in Partial Fulfillment of the Requirements for the Degree of laster of irts, in the University of Louisville.

$$
\text { June } 1913
$$




\section{PREFACE.}

The present study of the relieious element in the popular ballads is based largely on Mr. George I. Kittredge's edition of Mr. Francis J. Child's collection of English and Scottish popular ballads, the completeness of which, up to this time, has not been disputed.* Mr.Kittredge has printed in his volume one or more versions of every ballad which Mr. Child has given as an authentic folk ballod (omitting Nos. $33,279,281,290$ and 291), besides including a few of somewhat doubtful origin. It has not been judged necessary for the purposes of this article to discuss more than one version of any balliad, except in cases where a significant development of thought or custom is brought out by the different versions; conseyuently Iir. Kittredge's single volume has been found most convenient and adequate.

The numbers and names of ballads to which this paper refers are those used lay both Mr. Child and Mr. Kittredge. The notes of both of these scholars have been consulted and quoted frequently and freely. The present work makes no claim to originality, but purposes to consider the ballads from one standpoint, their relation to the Christian reli- 
gion and church, applying to the whole serieg the same touchstone, and grouping the facts which this test brings out under suitable headings.

Louisville, Kentucky, June $\cdot 5,1913$.

* Bnglish and Scottish Popular Ballads, Edited from the collection of Mr. Francis James Child, by Helen Bargent and George Iyman Kittredge. Houghton, Mifflin Company, Boston.

The English and Scottish Popular-Ballads, Edited by Francis James Child. Little, Brown and Company, Boston. 
INTRODUCRION.

How far Christianity played a part in the literature of the ballads is a matter difficult to determine. Many ballads contain stanzas dealing with Christian ideas and institutions which, on inspection, show that they have been added to or incorporated into the ballad at a different period from the time in which the main stanzas originated. This process of adding to and modifying the first composition naturally and unavoidably attends oral repetition ana transmission. Words, phrases, and even stanzas which tell of customs that have died out, or the gnificance of which has been lost, are supplanted by expressions containing more recent material. In this connection one finds changes of eplthets, variations in the way of local color, the substitution of well known names for those whlch have been forgotten, and, in many cases, a complete working over of the material, so that a heathen or fairy story becomes a Chriatian myracle tale with appropriate setting and circumstance.

It is unnecessary in this article to consi-. der or enumerate the Latin or French manuscripts that dealt with religious material of various kinds during the Anglo- Saxon period and following. That learnod priests ana students wrote in Latin lives of saints, discussions of religious problems, sermons and com- 
pendia of sacred anecdotes and exempla is well known.* That the Norman Conquest brought in a scettered library of French material on the same subjects is also granted. The question to be considered here is, how this material reached the people at large, and became so well known as to be worked in course of time into the form of the popular ballad.

One may, in this study, go back as far as the time of caedmon, when Whitby formed the center from which the religious life of the community emanated. The storieg tell us that Caedmon was shamed because he. could not do his part toward the entertainment of the household by song or story. As he was an unlearned man, a rough herdsman, according to Bede, * one draws the conclusion that the humble folk of the monastery, and doubtless of the whole neighborhood, were in the habit of gathering, at-times, in the hall, for social intercourse. That part, at least, of the entertainment should be of a religious character is to be supposed, and Caedmon's subsequent fame in his päraphrases of the Bible tells of frequent and much enjoyed rehearsals of his work in just such gatherings. Tradition credits caedmon with the translation and paraphrasing of a very large portion of the Bible, but critical students ascribe the major part of this to contemporaries and followers. If it is a compilation, the fact is even more important, from the widespread knowledge of the Bible that it indicates.

*Bee Juseerand' IIterary Hist. of the Ing. People. 
According to the account of Bede, * there were many at that early time exercising their gifts on the same material. Besides stories or poems based directly on the Bible, Innumerable legends of the saints served the purpose of keeping the religious spirit alive among the common people of England. Cynewulf'g eighth century verse brings into prominence the value of the legends of the saints for literary material, and his rather free and fanciful account of the life of Christ foreshows the trend of English religious liberature in succeding centuries.

The influence of Whitby in the literary North affords an example of the importance of the monasteries as distributing centres of religious knowledge. It is possible that the priests in the adjoining chapels or churches had even then initiated the telling of the fascinating Bible stories, and perhaps, occasionally, the legends of saints, such as formed so large a part of the later church service. Bede's translation into Anglo- Sazon of the Gospel of Saint John was the last impulse given by literature to the dissernination of religion in the North, so far as we have any evidence. The spread of the common knowledge of the Bible and religious belief must have continued through the efforts of his many hundreds of pupils, but the besom of the barbarian invader has swept away all literary 
evidencenof their work.

The invasion of the Danes effectually put an end to learning of any kind throughout England. Priest jobned wi th layman to save merely ife and limb, and all the Church was able to extract from the wreck was a saint or a martyr who had died in defense of his country.. The English Saint sebastian, so well beloved in eastern England, met his death in this s.torm.

When Alfred and his forces arranged the peace that allowed domestic life to be resumed, religious learning had declined to the extent that there was hardly a man, according to Alfred, *south of the Thames, "who could explain his service book in English." Owing to Alfred's indefatigable efforts, schools were established for the education of the people as well as academies for the sons of nobles. The practical value of these schools lay in their aim to teach every free born youth to read his native language. One reads of the learning of priests, or of their ignorance, but the fact of the popularizing of the first steps of education in the instruction in reading Anglo- Saxon, answers, to a limited extent, the question 80 of ten propounded as to who made up the reading public for which the mass of early English translations, chronicles, Jusserand's Iiterazy History of England, $p .81$. 
saints ${ }^{\prime}$ ives and bestiaries were written. From the writings of Asser, the man who was to Alfred what Alcuin had been to Charlemagne, one learns that monastic and episcopal schools were established for the nobility, and that many persons of the inferior classes also attended these schools. Asser, in his discussion of the times; says;

"Every person of rank or aubstence who, either from age or want of capacity, was unable to learn to read, himself, was compelied to oend to school either his son or a kinsman, or, if he had neither, a servant, that he might at least be read to by some one."

The Impulse ghven to education by Alfred was not completely lost in the succeeding centuries. Dunstan and Canute each did his part to further education, and the Confessor had high ideals of national improvement along this line,

In spite of wars and internal disturbances that must have constituted a serious interruption to Iiterary composition, a large mass of Anglo-Saxon writing has come down to us. Among these remains are translations of the Heptateuch, the Pseudo Gospel of Nicodemus, fragments of Judith, various translations of the four Gospels, excerpts from Ecclestasticus, besides numerous hom- 
ilies of Aelfic and others.

of these works Mr. Morley says; " those who wrote in the mother tongue ( after the fourth century) did so for the delight and instruction of the multitude, each using the homely English of the neighborhood in which and for which he wrote." This statement, in 1 tself, tends to the inference that Mr. Morley considers important a reading public not entirely composed of the priesthood. During the time of Aethelwold the people as well as the priests were allowed to read the scriptures in the native tongue. The anonymous translation of the Bible made in Alfred's time was re-written during Dunstan's rule over the English church in the dialect of the period.*

Al though the reading Anglo- Saxon pubIic must not be disregarded, it is never theless indispitable that the main instruction of the people came from the Church, and directly from the pulpit. The greater part of the Anglo-Saxon literature, as well as the literature of the early Norman period, consisted of religioud writing in the form of homilies or allied naterial which could be used in the Sunday services, or to enliven the celebration of the various holy days of the church. The homilies which have been preserved contain masses of extra- 
neous matter, as we should now consider it, such as " Iegendary information concerning the Holy Land, with minute pictures of the devil and apostles, with edifying tales full of miracles."* Aelfric himself filled his sermons with an extravagant mixture of Christianity and heathen superstition, transformations and enchantments, apparitions and magic dis: 1 . appearances.* He also frightened his flock into the narrow road by his dramatic account of the devil and his ways. One infers that the association, in? the older ballads, of Christian idea and heathen superstition, of devil and elf, of the Blessed Virgin and the queen of the fairies, of the efficacy of prayer and the magic of spells, received its sanction and perhaps its impetus from the pulpit.

It must be remembered that the English church, so widely removed from the seat of authority at Rome, exercised unusual freedom, being permit: ted to carry on a large part of its services in the native tongue. Lappenberg states that the mass itself was not entirely in Latin, and that, in his opinion, the wedding form was entirely in Anglo-Saxon. *

One is led to believe that the various compendia of lives of saints, such as Aelfric compiled, or those translated from Bede's Iatin work, were ex* Jusserand, p. 89.

I Ibid. p. 90 .

2 F.J.Snell's Age of Alfred, p. 227. 
tensively used by the priesthood, who were in the habit of refreshing their memories by reading these accounts of martyrs and saints before each saint's day in preparation for the following day's sermon to the people.* one finds in the ballads frequent and ramlilar mention of the soints, both of apostolic times and of later canonization. St. Peter, 'st. Paul and st. John are the favoribe patrons. of the balladisto, and besides these, one finds mention of St. Evron and St. Mungo and of Saint Mary Magdalene. The frequent telling of the lives of the saints bears little direct result in the ballads, but the indirect consequences are $f$ ound in the accounts of crude magic and supernatural achievements that savor strongly of the Sunday homily.

Besides the use of the lives of the saints in the homilies, the Church drew freely upon the apocryphal books which arose in the early centuries of Christianity and inculcated the most astounding ideas concerning the chief characters of the time of christ.

Even in its pre-Conquest days, the Church provided a certain degree of dramatic representation in the services on high days. The liturgical dramas which assumed so elaborate a form in the thirteenth century and afterward, were not the result of spontaneous genius, but a slow and cautious development * Snell'a Age of Alfred, p. 232. 
of early pictorial representation in character, which, in time, took on motion, and, at last, speech.

Outside the church and monastery, one finds in the faies and the moot courts centers from which the knowledge of the Bible and religiou lore may have been spread abroad.* Market days and fairs are as old as the soclal life of the human race, and oyr ancestors met for exchange at periodical fairs as far back as our accounts take us.. At these gatherings all the means of entertainment known to the Teutons were carried on. One could hardly doubt that a good talker, other layman or priest, could here gather his audieneec (as did the Bishop upon the bridged*I who would Gladly listen to his stories of sacred history, embelII shed, as they were, wi thitales of the most astounding marvels and miracles. A returning pilgrim must have been welcomed with delight, and the fact that the tories told by these men of their travels were as wildly imaginative as those of Sir John Mandeville or Marco Polo of later date, comes down to us in the descripttions extant of Jerusalem and its relics*2Besides this material. the traveler had become acquainted wi th new versions of the old stories; an added miracle accredited to a saint, a new marvel told of the Infant Jesus, an oriental tale rehabilitated in Christian garments. From these fairs one imagines that the countryman bore *F. York Powel, in H.D.Trail's Social England, p. 140. * Ischafield's Hiatory of English Literature, p. 18.

2 See extract from the Blicking sermon on Ascension Day given in Snell's Age of Alfred, p. $211,212$. 
back to his native village or farm many a tale of saint or martyr which, one may be sure, lost nothing in its rehearsal about the flre, or at the board.

The praxtidy or annual courts doubtlese partook somewhat of the same social character, whether hell-moot, hundred-moot or ahlre-moot.* This democratic institution dates as far back, mong the reutons, as the time of Tacitus, we know, and was continued up to the conquest and on into modern times with changes in name and ol roumstances, but not in character.

Af ter the Conquest, while the old customs of cocial intercourse continued, new means of disseminating knowledge arose. The adrent of the friars, In 1220, increased greatly the communication among the yeople. simple religious knowledge was carried about by these men, who wandered up and dow through the land, exhorting the people to religioul life. The Normans, moreover, improved the rosds by putting them In charge of the monasteries, and travel became constant. Besldes the monasteries as houses of entertainment, inne sprang up at the oross roads, and the inn kitchen became a place of social gathering among the middle clase travelers. Jusserand, in his Wayfaring life in the Ilddie Ages, gires an sccount of the incessant flow of travel in this time, caused, in * P.York Powell, in Irail's social Ingland, p. 136. 
part, by the Norman pollcy of bestowing widely separated properties of the feudal lords, thus obliging them to move Irequently from place to place in order to maintain their large retinues on their lands.*

The Norman barons, as they moved from castle to castle, carried with them, one may surmise, portions of thetr libraries; perhaps a massive volume or two containing the most prized tales, or a collection of religious commentaries, with lives of the sainte and martyrs. In a short space of time, English translations of the most popular of these French and Latin manuscripts were made and added to the libraries of monastery and hall. For, not only did the Normans bring their books in French and Latin, but they brought what was more valuable, a new Impulse toward learning, which bore fruit in the Inglish tongue quite as much as in the French or Latin. Translations of the Goopels were made, and In 1250, a paraphrase of the firat books of the 01d Testament, by a scholar who thought that the peapte for wom he wrote "ought to be as fain as are the birds at daybreak when they are told sooth tales in their native speech with sall words of the hills of bliss and the dales of sorrow."*

One sees here that the reading snglo-8axon pubilo that was not learned was st1ll worth con- 
sideration. Another book written for the lal ty who could yet reas the Inglish was the Cursor Yund1, which arowed the purpose of giving the public something better to think on than the romantic tales then popular. This poem containa a quantity of legendary material and bases its claim to serlous consideration on 1 ts purpose of encouraging the adoration of the Virgin Mary.

The practice of including stories of the saints in the ohuroh service continued and malntialned its importance. But, in the thirteenth century; and perhap earlier,., the church enstituted a cult of the Virgin Yary for the purpose of refining some of the coarseness of the age. A romantic tone was given to the worship of both Christ and the Vitgin, and the customs and language of chiralry were taken over by the Church, ever ready to adapt its teachings to the trend of the times. Wile the influence of the saints' ifres is only oocastonal or Indirect in the ballad Ii terature, the deep impresei on made by the virgin cult is evident in sereral inetances, more ospecially in the group of Robin Hood ballads, where the adorae tion of the virgin is show to be a potent influence in the every day life of the people. 
It is unnecessary, in this discussion, to consider ballads written about an event of historical importance later than the fourteenth contury. The ballads can tell ue little of the religoius life of the leter ylddle Ages that cannot be invertigatiod more easily through the multiplied docunente of contemprary scholars . But, for the earlier period, before the printing prese had rerolutionised the literary world, the popular ballad affords erldence of unique value in the study of the intimate 11 fe and thought of the great Bnglish camons.

The mase of material in the older ballads that contains oridences of Chriotianity may be grouped under four wain ditibionp of which the largest is the cycle of ballads concerning the famous outlan, Robin Hood. In the second group may be inoluded those ballads, fow in number, that are founded directIy on Bible stories of the Hew and 0ld Testaments. The third croup is made up of ballads which show the popular hatred of the Jews, The last divisi on includes all other ballads, scattered throughout the collection, whioh contain allusions, direct or indirect, to the Chrietian faith or its coremonial. 


\section{THE ROBIN HOOD BALTIADS.}

The date of composition and the historical value of the ballads of Robin Hood have long been subjects of controversy. Hel ther the internal nor the external evidence on the subject has been of a character to locate theciate of the poems within a. closer period then two hundred yeare. The first mention of the Robin Hood stories 1s found In Plers Plowan, (1362) in which it 18. Intimated that the Rhymes anc Tales of Robin Hood are familiar to the common folk. It would, perhaps, be safe to assign 1300 as the latest dete at which these ballads could have had their beginning, but how much farther back they may extend is a questi on still open, and on whioh much may yet be said.

Robin Hood's attitude toward the institutions of the church forms one of the chief interests in the ballads. From the words and actions of their hero, one gat'ne an 1 dea of the popular sentiment toward the Churoh, and learns something of the ecclesiastical conditions of the time; consequently, the paseages on the subject, taken together, throw a light on the rexed question of the date of the ballads by connecting them with oertain knom facts in the history of the churoh. 
Robin Hood's relation to the Church way be -tudied under two hoads; (a) his sincorely rellglous nature and strict observance of his religious dutien, connected with whioh is his romantic derotion to the Virgin; and (b) his flerce scorn and hatred of the dignitaries of the Churoh.

Beginning with the latter of these phases, one considers tho period in which the churohmen had become hated by the Inglioh commons for thelr wickedness and arrogance, "These bishop and these archb1 shops, you shell them beat and bind says Robin. That this condition was posable in wore than one century is well attented.. Hatred and distrust of churohfunctionaries was common in the days of Edward the Confessor (1042-1066), who brought into Ingland numbers of forlign prieste to f1ll the higher offices of the Churoh in his rain endearor to reform the laxities pretaling among the regular clersy. On the other hand, there is nothing in the ballade to give one the impressi on that these churchmen are forelgners, or that the order of things 18 in any way new.. There is a certain contempt bred of familiarity, as though the decay were the result of yeare of ev1l practice within the body.* This condition of affairs could hardly hare come before the Conquest, nor hare * See W.Hi Bohofield's Hilt. of Eng. Ilt. fran Borman Conquest to Chaucer, $\overline{p p}, 57,58,59$ for i1 terature on the subject of orils within the church. The reader may refer directly to ratt. Pario' Chroniclos and to Walter Kap' Bi ghor Golias. 
grom up during the vigorous rule of the early Normans. The period at which the Church again fell prey to the rapacity of its heads may be assigned to the time of Henry III, about which much has been written, and which, in other ways, would well agree with the internal eridence of the earliest of these poems. However old the original stories of Robin Hood may have been, I should say that the thirteenth century would easily hold all the circumstances given in the ballad. that have come down to us about this hero. It may well be that the ge ballad are built on simllar lines to certain ballads composed in the previous century, but changed to sult the conditions and temper of the times. It is evident that Robin Hood's name formed a convenlent peg upon which to hand innumerable stories $X$ of outlawry and adventure.

The ballads of Robin Hood that deal with Robin's attltude togard churchmen are:

I0. 117. The Gest of Robin Hood. Ho. 119, Robin Hood and the Yonk: No. 120, The Death of Robin Hood. No. 123, Robin Hood and the Curtal Friar'.

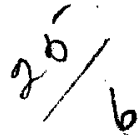

R. N/

No. 138, Robin Hood and Allan a Dalé.

\$o. 140, Robin Hood Rescuing Three squires.

Ho. 143, Robin Hood and the Bishop!.

No, 144, Robin Hood and the Bishop of Hereford.

110. 147, Rob1n Hood's Golden Prize:

* See J.R.Green's Short Hist. of the Bng. People

for an account of the misrule in the time of Henry III. 
The Gest of Robin Hood represents a collection of old ballads that have been subjected to slight changes in order to fit them into a comparatively consecutive story of the outlair. Prefixed to the collection are several stanzas of an introductory nature, which have a romance touch and will be considered in the second part of this discussion.

The f1rst Fytte of the Gest concerns a knight who is in debt to the Abbot of Saint Mary's for four hundred pound which he had borrowed to free hls son from the penalty of murder. This point may have reference to the old 1dea that a life had a money value. The price pald for a life, called in pre-Conquest days the "Wergild," became higher and hlgher after the conquest, and the law concerning it became extremely elaborate. According to F. W.Maitland, thi custom perished in the twelfth century.*

After receiving the loan of the money from Robin Hood, who is glad to do the Abbot an 111 turn, the knight proceeds to the Abbey to pay the debt.

The second Fyt te shows a scene in the Abbey where the abbot has gathered around him a formidable assembly, apparently for the purpose of coverawing the knight whose lands he is eager to hold, for they are worth fully four hundred pounde year. The knight, *H.D.Trail'g Social England, D. 171. 
at Robin's suggestion, one imagines, pretends, at first, that he 18 unable to pay the money and asks for an exteneion of the time. The abbot scornfully refuses the request and claims the land, but agrees, at the justice so Instetence, to pay one hundred pounds, no more, to the knight, for a release of all claims. The knight then throws down the whole sum of the debt, claims quittance from the justice, and rides away triumphant, to the exceeding discomfiture of the Abbot.

The fact that there is a necessity for the presence of men of law at the settlement places the date. of the poom as distinctiy post-Conquest, when the Church courte were separated from the civil courts and a civil justice must declde on mattere of civil lax The sheriff present at the scene was also a Royal off1cer who had his place la the local courts.

An interesting feature of the poem is the prior's remonetrance in faror of the knight. Although in a monastery ruled by an Abbot the prior was usually his appointee, the fact that the office of pricr was elective in many monasteries sets the prior in the class of the common folk with whom he may be supposed to sympathize.

In the fourth Fytte of the Gest Robin's fot: lowe capture the cellarer of the same Abbey of 
8t. Mary'., the "fat-headed_monk" mentioned in the first Fytte, and bring him, with about fifty of his men, to Robin, who is fasting until he shall have found some adrenture to begin the day. Robin Hood taunts the monk with mock courtesy. "Robin Hood did adown his hood, the monk when that he seef but the monk was not so courteous, al though Robin serrod him with a good dinner and the best of wine. After dinner when the outlew finds elght hundred pounds in the monk's chests, he assures his captive that it is the direct gift of st. Mary, for whose sake he had lent half that sum to the knight. That the money comes from the very Abbey concerned in the former transaction makes the chance all the more pleasing to Robin.

After dispoiling the monk of his money, Robin sends a mocking message to the Abbot, and releases the monk, who, the ballad says, is on his way to a "mote" in London, where his Abbot is to seok vengeance on the knight. This passage may have reference to the more centralized government established by the Normans, under which disputes about land were referred to the king's court. In the serenth Jytte of the Gest, the king, named Bdward, destring a meeting with the outlaw who is despolling his forests, disguises 
himsolf as an Abbot, and, followod by his rotinuo olothed in the Groy gowns of the monastary. rldes boldig Into the foyest. Ho sooms to place h1s soourlty on the stortes of the conntry folks to the offoot that Robin Hood spares the porsons of ohurohnon while he robs tholy purses. The party is mot and haltod by the onslawe. Who demand moneg. To the1r orddent onxplso, tho supposed Abbot hands them orer Iorty pounds, olalnd ne that this wn is all he has left aeter his reoent ratt to the king. BobIn moots oourteas with courteng and takes but hale the sum for hie mon, rotorning the ronalnder to the monk for his om oponding. After a pleasant hour in the wooks, Anxing whtoh Robln takes oooestion to send his roepeots to the king. the outlawe try tholr arill at ahootine at the mark. $\Lambda$ penalty Lor mlsalne. Bobin rooal7as a Inaty buffet from the Abbot, at whom he now looke olosely, and whom ho

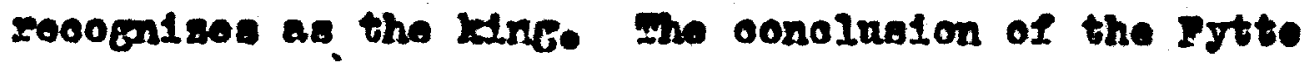
18 more rovant1e than that of the previoun atorler. and soon to point to a Iater orfetn. although thore Is nothing detinite on whioh to base this opinion. BobIn adks forgtronose of the late and agrees to entor h1s sorvioe. A rozg proteg dosoription of the kine and hla Nllowers in the monkish "woede" 
ooours in stanzas 372, 375, and 374.

The elghth Fytte takes up Robin's Ilfe In the king's const, of whioh he soon grows weary. Ilo obtaling seven days' leave of absonce Irom the retne on the protonoe of making a plierimage to a ahrine of laxy baglalene whioh he soons to have built. Fo lesoribes the pilgrim's oootum, a sheep's akin with the wool turned inward, and proposen to walk there barefoot. whe king erants him eoven n1Ehta' leave, but Robln 1s nover again soon at oourt. The ballad makes no montion of Robin's over sooking the ahrine: but he $1 \mathrm{~s}$ soon back among his follow, living on the king's doer. Bobin Hood's ond, aosording to the Gost, 18 through the treachery of a moman, the priorece of KIrkly Abbeg. Proublod wth a forer, Robln sooks the atd of this prazoss who 18 aktilod in 10echoraft. At the Inatigation of an energ of the outlaw, the prloreas allowp Robin to bleod to death sion the oxppline.

In 10. 129, Bobin Hood and the Bonk, the attitude of the oomon folk toward the monks 18 forolbig brought ont. milo Robin 18 in ohuroh at Dottingham, he 18 rooochized by a "Eroat hoaded-monk" who hastong to arouse the shersef to oapture the 
outlaw; for Robin, he claims, had formerly robbed him of a hundred pounds. The same Monk, bearing the news of the capture to the king, is waylaid by Iittle John and brutally killed. Ilttle John expresses no compunction at the deed, which speaks plainly of the popular attitude toward the monks. One can but feel, however, that the more gallant Robin would never have permitted the violent death of the monk, if he had been on the scene.

That churchwomen share with churchmen the popular distrust is evident in Ho. 125, Robin Hood's Death, which is a more elaborate version of the story of his death told in the Gost. In this ballad Robin is warned against the prioress, but truste in her kinship to him. She takes Robin's proffered twenty pound before bleeding him to death. Robin, however, has his revenge on Red Roger, the instigator of the crime, although he will not allow the nunnery to be burned by his followers.

No. 123, Robin Hood and the Curtal Friar, bears indications of being a ballad of later date than the ones previously dealt with. In this stoxy Rowin enters into a trial of strength with a friar who is represented av wearing a headpiece and breastplate. There is an amusing contest between Robin 
Hood's followers and the friar's ban-dogs, which ends in the friar's agreeing to join Robin's band. The points of interest in the story are these Iacts; that the friar is dressed in armor, and that he is stationary at Fountain's Abbey. As to the first point; in the Auchinlech Manuscript a poem "On the Bvil Times of Bdward II" sets forth the low state of the Church in which the opirit has given place to the body. In this the author says. "Abbots and priors counterfert.knghtef mich suggests the idea that military equipment might not have been unknown to even the humbler members of the church body. That the friar had been stationed at Fountaln's Abbey for seten years speaks of the degeneracy of the Iriars, who, at their coming to England in 1220, maintained the rules of their order which commanded a wandering iffe.. Thi friar seems to have held the post of guard at the abbey, and was thus allowed to tuak up "or courtal" his robe in the pursuance of his domestic duties.

"Robin Hood and Allan a Dale", Ho. 138, may be a later ballad, but it has the characteriotic reckless good nature of Robin, though lacking in reverence for the rites of the church. In this -tory, Robin and his followers tnterrupt the bishop in the performance of a marriage ceremony in order to 
restore to Allan a Dale his sweetheart, about to be married to a rich old knight.

"Robin Hood pulled off the bishop's coat And put it upon Little John,"

and adds insult to the injury by his words, "The cloth doth make thee a man, intimating that the prelate ras: a bishop only by virtue of his coat. Little John carries out the mock wedding by asking the bans seven times in the church, "Lest three times should not be enough."

In Jo. 143, Robin Hood and the Biahop, the outlaw at first shows fear that he may be captured and hanged by the bishop,, who has come into the woods with a great company. By the help of an old woman whom he had formerly asoloted, Robin in disguise tricks the bishop and decoys him into the midst of the outlaws. After robbing the bishop of five hundred pounds, Robin ties him to a tree and forces him to sing mass to the outlaws. After the unwiling service, he dismisses the bishop, setting him upon his.horse backward, and giring him his horge' tail in his hand.

This rough treatment of a prelate is told again in No. 144, Robin Hood's Golden Prize, which 18, according to Mr. Kittredge, a comparatively modern verai on of an old tale.* In this ballad, Robin Hood, disgused as * Bnglish and Scottioh Ballads, p. 347. 
a friar, goes through the woods "wi th hood, gow, beads and crucifix," until he comes upon two priests of whom he begs alms.. At their refusal Robin drags them from their horse, forces them to pray for money for an hour and then searches them. He finds a "good store of gold," of whlch he gives the priests a share, "cause you prayed so heart1ly," and makes off with the rest, dellghted at the joke he has played.

It is remarkable thatioin the older and genuine popular ballade of Robin Hood no mention is made of a parish priest. Yet we know that the English parish priest continued his duties in his humble way, while the Frenchmen, or the more influential Inglishmen, held the rich offices and lived on the fat of the land. Wllliam and his followers had no interest in displacing the Anglo-saxon priest, but were glad to permit him to continue in his arduous and humble duties. Perhaps the parish priest was too lowly a person, too much one of themselves, for Robin Hood's company to notice. Robin could have no enmity toward them as a class, for they were poor and $\mathrm{kin}$ in race to the outlaws, probably symathizing with them in their struggle against Church and atate oppression. 
Robin Hood's Religion.

Although Robin Hood evinces scorn and dise-spect toward the higher digattaries of the church and the regular clergy, he maintaine the deepest reverence for the institutione of religion. He must hear mass frequently; In fact, according to the introduction to the Gest, he 18 in the habit of hearing three masses a day. He is sometimes hard put to $1 t$ to perform his religious duties, and must resort to dangerous expedients to carry on his devotions. In IO. 119, Robin Hood and the Monk, "he bemoans his outcast tate on one account only; that he may not attend waws or matins on any solemn day. The fact that a fortnight has paseed "gyn I my savior see", drives him to the desperati resolution of venturing into Nottinghem, where he is well known and well hated, to attend mass. The death of the monk who recognized Robin and caused his capture cannot be laid at Boldn's door as it was done without h1s knowledge. However ruthlessly Robin may rob and abuse the prelates that fall into his power, his religion is too sacred a matter with him for him to permit actual injury to a representatire of the Church, eren though he may deem the churchman unworthy of his office.

Throughout these ballads, oaths of Christ, the Trinity, God and the Virgin yary are erequent, but they are used somewhat reverently. There is a strong 
contrast between the tone of the expletires in the genuine Robin Hood ballads and that of the oathe in the later and coarser imitations.

The first ten stanzas of the Gest, which may be taken as introductory, have a romance touch that proclaims the influence, if not the hand, of the artist minotrel. Gentlemen of free-born blood are asked to harken to a tale of a good yoeman. A few stanzas down, Robin himself says that he has no desire to dine unt1l he has performed some strange deed of sport or valor, or has captured and robbed a baron, knight or squire. One is reminded of the scene in Sir Gavain and the Green Knight, where Arthur delays to dine until he has been adrised of some knightly deed or trange adrenture. The strongest characteriatic of the Robin Hood ballads $~$ that makes for romantic interest is Robin's devotion, genuine and consistent, to the virgin.

\section{The cult of the Virgin.}

The elevation of the Virgin to a high, elmost the highest place, in the estimation of Christians was, In part, the deliberate effort of the Church toward refining and uplifting the great mase of the people. since the early days of the Christian Church, the softer and gentler aspect of religi on had been taught largely through the worahip of the Vidin vary; but the cult of the Virgin encouraged by the Church in the Middle Ageo 
was of a different nature and inaugurated for a somewhat different purpose..

vith the commingling of the races, Horman and Anglo-saxon, the saxon 1deas with regard to women that had hitherto prevalled had undergone change. In time women no longer held the position of dignity and importance that they had maintained by right of theor coutonic blood. Chivalry came in to lift women again in to prominence, but into a prominence of another king, where their claim to importance and consideration lay, not in their position as mother and respected partner in the direction of the household, but in their more romantic nature as weetheart and inspirer of knightly deods.

It id easy to see what was the outcome of this change of idea in the position of women. Mhen, in course of time, the knightly 1deals sank to a lower level, women became no longer the prize of chivalrous deeds, but the prey of otrength and rapacity. This sentiment, opreading from high to 10r, caused great concern to the serious churchmen, who began to devise some means of lifting the minds of men to higher things. They procooded in a way that seoms strange to us, for, instead of endearoring to improve the conditions of ocial intercourse between men and women; they set about to 
turn men away from human love to the love of the virgin. Innumerable tales were written for this purpose by monks and clorks, and used in the sunday service as part of ; or in place of, the homily. Many of these stories, but only a small part of the whole number, are preserved in the Vernon Yanuscript as the so called "Yiracles of our Lady." The benefits promised from the worship of the Virgin are great and numerous; the mere listering to the. story of her deeds would bring an indulgence of forty days.

The Introduction to the "Cursor Mundi" Gives a good Idea of the prevalibg conception of the worshlp of the Virgin Mary. In the poem, composed in 1320, the author says, according to Mr. Schofield, * that he will -ing of the Virgin," lady more true,, loyal and consant than any other, more beautiful and ready to reward: Appended to the "Cursor Yundd" is a poem on the same order, "The Assumption of Our Lady," composed about the middle of the thirteenth contury and based on an old tale widespread orer Burope. The story in the Vernon Manu-. script of "A good Knight and his Jealous Wife," tells of the stirring of jealousy in a wifecwhose husband admits that he loves another (moaning the virgin) better than he loves her.

The effect of these stories on the people of *Bchorield's Engliah I1t.,p.376. 
the time is plainly to be seen in the Robin Hood ballads. The ballads, moreover, take us one step further, for in them the reaction has set in in faror of the women themelres. Robin Hood's dototion to the Virgin, full of sentiment and romance, has produced the result desired by the promulgators of the cult in elerating all other women in Robinge eyes. That the popular hero should hold all women in high respect on account of thelr relatian to the virgin yary shows, if not the popular custom, at least the popular ideals, on that subject. In the introductory otanzas of the Gest of Robin Hood, the religt ous convictions and observances of the hero are tated in tanzas 8,9 and 10 . He hears three marres dally, one forrthe Father, one for the Bon, and the third for "Our dear Lady," that he lores the most of all. The tenth sanza explains his sentiments:

\section{"Robin loved Our dear Lady, Bor doubt of deadiy oin, Vould he never do company harm That any woman was in."}

To this determination he adhores even when, in the last Fytte, he has been betrayed by the nun to whom he has gone for assistance in his 11lness. He stoutly refuses to allow rengeance to be taken on the womap after she has betrayed him to his death, or to permit his men to burn the hall (the nunnery) in which there are widows. In the last part of the flrst Fytte of the Gest ,Robin takes the pledge of the knight for the re- 
payment of the money Robin is to lend $\mathrm{him}$, when the knight calls upon "Our dear Iady," who he says has nerer failed him. With enthusiam Robin greets this fellow derotee:

$$
\begin{aligned}
& \text { 'By dear worthy Gad, said Robin, } \\
& \text { 'To search all ingland through, } \\
& \text { Iot found I never to my pay, } \\
& \text { A much better borrow. 'in }
\end{aligned}
$$

The romance touch spoken of in the introductI on appears in the fourth Fytte, where Robin expreses Fear that Our Iady is wroth with him, as she has not sent him his pay, by which he means some luckless travelor whom he can rob. He foels that he is forgiven and: again in faror when his men bring him a monk and his company, whom they hare captured on the highroad. RobIn insists that the monk has been sent him by the virgin, whom, by the way, he refers to as "God's Dame," to repay him for the money ho has lont to the knight in the virgin's name. That the captured monk is the collaner of the Abbey to which the knight owed the money makes the stary of still greater point, and confirme Robin in his coneciounebe of the Holy Virginf faror.

Passing from the Gest to the separate ballads that have the genuine popular ring, one finds in Wobin Hood and Guy of Gisborne;" thet Robin, who has unluckily stumbled over a root in his fight with Guy, calls upon his Dear Lady, and id soon upon his feet again, fighting with renewed eteength. In this connection it 
Is worthy of note that no direot miracies are ascribed to the Virgin in the Robin Hood Ballads. Although her ald Is trequentig Invoked and her assiotance taken for grant- $\checkmark$ of In a general way, nothing miraoulous, such as one might expeot in a tale of the niraolo lovine folk, ooours to ahow her alreat interposition for the ald of hor, deroted worahiper.

In 10. 219. "Robin Bood and tho Monk", Robin hopes to be ablo to hear mass in Hottingham, the home of h1s onories. "with the might of mild lary". When be reaches the town he pragt to kary to bring him ont safols. After his unfortunate oapture, Ifttle John bases his hope of offectine a rosoue on the known faot that

"He(Robin) has aervod Oar Iady nany a day And $70 t$ w11 onroly. Therefore I truat in her opeolalig Ho wloked loath thall he d10."

With the help, then, of Mll lary. Ifttle John onsnares and k1118 the wonk who 18 boarine th the king the nowe of Robin's oapture.

In one of the later ballars, Ho 123, "Robln Hood

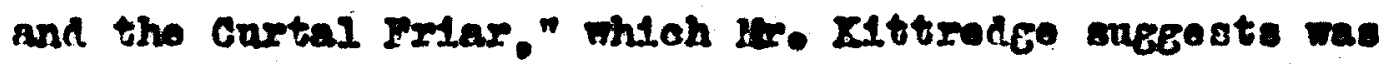

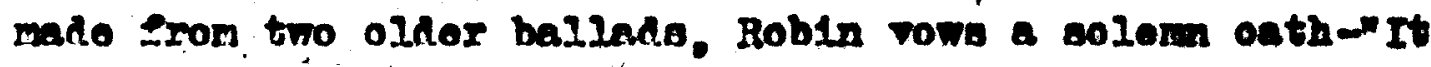
was by rary Iroon'- that ho m1I moet the sturdy Iriar and have a bout with himo

The later ballads and broadoldes bullt upon the oarlier ones add nothling to the evidenoe on this subjeot. thoy ahow an Inoreasinc lowty and a lose of the original serlonsness that is oharnoteriatio of the real Robin's roliglons conviations. 
Bealads Founded on Biblical Yaterial.

The part played by Christianity in the literature of the bellads, in general, has been discussed in $\ldots$ the introduction to this article; for the prosent division of the subject I hall consider only those ballads which are founded on distinctly Blblical naterial. In this connection I shall discuse how closely they adhere to the original Bible story, and the nature and eburces of any changes in the atories that have come into the metrical form.

The ballads in $\mathrm{Mr}$. Child's collection that are founded on incidents related in the Bible are strangeIy few. Those baned on Hew Testament stories are:

Yo. 21, The rald and the palmer.

Ho. 22, St. Steron and Herod.

I0. 23, Judas.

I0. 54, The Cherry Tree Carol.

IIo. 55. The Carnal and the Crane. $\checkmark$

10. 56, Dires and Iazarus.

The ballad of "The Vandering Jew" way be appended to this list, on account the firm bellef in this chatacter current among the people of surope for hundreds of years.

Poseibly the oldest of these ballads are " "Judas" and "8t. Steren and Herod." Wi th the se $1 d$ placed "The Maid and the Palmer," which has the old ring and may be of equal age. The other ballads in the group 
are of a different type.

St. Steven and Herod.

The ballad of"st. 8teron and Herod" Bo, 22, presents a remarkable mixture of sereral Bible stories, including the stories of Herod, the Star, steven' martyrdom, and a cock, which may, in the first place, have had ome connection $w 1$ th the story of Peter.

The Herod tory was early a part of the comknowledge of the people. The dramatic value of so perfect a type of the villain could not be neglected by the practical morallsts of the church or by the tellers of tales. The foundation of the story 1 contalned only in the Gospel of Yatther(II), In which the wise men, seeing the star, follow it th Herod's court and tell the king of 1 te elenificance. Herod' treachery in endeavoring to locate the birthplace of the child 18 folled by the secret departure of the wise men, but the king's rage and fear lead him to order the ruthless destruetion of all the infants in the city. That Herod, as well as steren, in the bellad, considers the child a Iuture temporal king 18, perhaps, only the natural feeling of a usurper on the throne, who fears the 10 ss of his 1ll-gotten power.

That steven's death should have been ascribed to Herod arose, doubtiess, from the confusi on in the 
popular mind of the three Herods who ruled in Palestine during Christ' life and immediately afterward. The common midd could more readily understand the martyrdom of steren as the result of an act of tyranny on the part : of a monaroh than as a judgment decreed by a dim and little known sanhedrin.

The story of steren is found in ActeVI-VII, and his martyrdom occurs af ter the death of Christ. His stoning seems to be a formal execution, and is carried on according to established custion.

In the ballad, steren is giren as a steward in Herod's hall, who serves the king with a boar's head. In his passage from the kitchen to the dining half ho sees abore Bethlehem the star which he had been taught should indicate the combng of the new king. He renounces forthwl th his allegiance to Herod in favor of the rightful king of the Jewioh prophecies. Herod responds by saying that the new king's coming is as true as that the capon in the dion shail crow, and at once the bird crows, "Christus natus est," in miraculous confirmation. Herod, enraged, orders steren to be taken by the tormentors out of the town and stoned to death. "Therefore"" says the ballad, "1s his (steren') Eren on Christ's own day."

The only point of resemblance between the story of steven in the Blble and in the ballad, with the 
exception of the mapner of his death, is bis fine spirit of deflance. In the ballad steren casts down the boar's head with the same exaltation of mind and disregard of consequences with which, in the Bible narrative, he upbralds the council sumoned to try him for the stubbornness of their ancestors, and casts in their tweth theis own wicked acts against God:

The cock of the ballad story is hard to place. It is an important feature in all folk lore and 18 eren Given a semi-miraculou place io the scriptures in connection with Poter' betreyal of Chriet(Yatt., Mark, and Luke). According to Mr. Kittredge, * the miracle of the roasted cock occurs in the legend of steven and Herod In many scandinavian rersions, and is also a part of the legend of the Pilgrims of st. James, besides having a place in the apocryphal Goopel of Iicotemus.

Besides reaching the masses by the unual means by which the Bible otories were circulated; in translations, paraphrases, legends and homilies, the story of Herod was placed before the people in a most impreesive form in the liturgical drama, as early, on the continent, as the eleventh century, and probably soon af terward in Fngland. It made a part of the winter Festival, the celebration of the rpiphany, and was variously styled "Tres Reges," "ragl," and "Herodis and Stella." 
This act was given in the church with small scentc ad- . dittorg, a throne, th which sat Herod, and a movable star which led the three wise men to the king. * To th1 foundati on was added Rachael and the slaughter of the Innocents, in which children and a lamb bore a part. The whole was sung in a kind of dialogue or intiphonal chant. This form of church instruction, al though given in Latin, could readily be uncerstood by the audience, who were taught, oren after the Conquest, by their native priests.

That steren 1s found in juxtaposition with these characters is due, poselbly, to the fact of Bt steven's day 's falling in the same season, that of the winter Festival, celebrated oince heathen times and carried into Whurch calendar.

\section{Judas.}

The ballad of Judas exists in thirteenth century writing, the oldest manuscript of a ballad extent. From the fact that almost all of the ballads that have come down to us are preservod in manuscripts of much more recent date than the erident time of the ballad origin, it is probable that Judas also was composed sometime before the thirteonth century. It is well known that tories from the Bible and from the apocryphal scriptures were a part of common knowledge from 
early times.* "Changes in these stories would naturally be greater and of more frequent occurrence whep the incidents were learned through oral transmission than when the sources were numerous and accessible.

On the other hand, from apocryphal times down, churchmen themselve spent their time enlarging on the meagre relations of the Blble, and in plecing out from their exoltod imaginations distorted and marrelous var1ations on the original themes. In a writing of the same century as the balled manuscript is the account of the lives of Judas and Pllate in which the most miraculous incidents in the lives of these two men are recounted.*

In the ballad of "Judas," Judas is given thirty pieces of aller by Jesus with which to buy meat for the disciples. On his way through the streets, he is met by his wicked sister, who upbraids him for his allogiance to Jesus. Judas assures his sister that it 1. well that his lord does not hear her, for he would take vengeance on her for these words. His sister then persuades Judas to take a nap, wh his head resting in her lap. When he arakes $\mathrm{h} 1 \mathrm{~s}$ sister and the money are both gone, and Judas flees in a frenzy of dismay.

The bailad expleins Judas' subsequent conduct mont nafrely. He sems to have felt fear of appearing * Schofield, p. 377. * schofield, p. 378. 
before Jesus without accounting for the money commlted to his care. In his anxiety to how to advantage before Jesus, Judas obtains the money by selling Jesus himselt to P1late for the thirty pleces of silver, with which he then purchases the food.

There 10 a most peculiar effect produced by the idea that Judas should have been afraid to face his master wi thout accounting for the money, yet should not have been afrald to sell him to his enemies. The remote 18 less terrible to him than the imminent, regardless of the proportional gregity of the sin or ite probable punishment. At the meal in the evening, Jeous, encouraging his disciples to oat, tells them that he has been bought and sold that day for tholr meat, at which Judas asks if it is he that his lord suppects. Peter then boasts of his fidelity and recelves the rebuke as given in the Bible.

The main facts of the story in the ballad are, of course, taken from the Bible; but at wat date the Bible account was changed it is impossible to say. Mr. Kittrodge suggests that cupidity was supposed to be a motive for Judas' desiring to sell Jesus, and instances Judas'chagrin at the uselese expense of the ointments uned by Mary(John XIII, 3-6).* John tells us once again

Eng. and scot. Ballads, p. 41. 
that Judas "carried the bag," and gives us to underptand that the disciples kept their money in a common fund which Judas dispensed at Josus' orders.

The Biblical text upon which the story is based 1. found th John XIII, In whioh Josus, after indicating his betrayer, by handing Judas the morsel of bread, bade him $g 0$ and do quidoky that which he was to do. The $t$. text goes on to say that the majority of the disciples, not knowing the significance of the words, thought, when Judas loft the room, that he had been commiseloned to buy provitatome for the coming foast, oince he carried the bag containing the common funds. Peter's part in the ballad 18 also taken from this chapter, in which Peter bossted of his fidelity to Jesus, even unto death, and Jesus reproved him saying thet Peter should betray him thrice ere cock-crow.

It is rather strange that nothing should have beon sald of the prophecy concerning the crowing of the cock in this ballad where it would naturally belong, when it is made so important a feature in the ballad of Herod and 8teven with which it has no Biblical connection.

The Ideas of the early'fathers on the character of Judas may be found in the apocrypha to the new Testament, the early treasure house of miraculous stories on Biblical subjects. 
The Maid and the Palmer.

(The Samaritan Woman.)

The ballad of Uhe Mald and the Palmer" tells the story of a maid who has gone to the well to wash when an old palmer cones to the well and asks for a drink. The maid refuses to draw him a drink, saying she has no cup or can with which to draw from this deep well. To this the palmer responds by showing her his knowledge of her evil life. There is a certain sibllarity here to the ballad of the "Cruel Mother", Ho. 20, in the, accusation made by the palmer that the woman has killed her children and secretly buxled them. The mald protests hor innocence, wrearing by good saint John, whose Gosper has preserved the original story of the Samaritan woman. The penances imposed by the palmer are of the fantastic nature of the rery old stories: that she shall for ceren years be a stepping-stone, for seven years a clapper in a bell, and for a third period of seren years she shall lead an ape in hell, after which she shall be forgiven.

The ballad has none of the high opirit and dignity of the Bible rersion, John IV, 4-30. The main. incidents of the request for a cup of water, the refusal, and the miraculous knowledge of the woman's iffe dieplayed by the palmer are identical with the Scriptural version; but the tone of the ballad is so differ- 
ont as to have made this identity doubtful, if, acoording to $\mathrm{Mr}$. KIttredge, * it were not for several scandi. navian rersions of the same story which name the woman Yary and the man Christ or Jesus. Although the Latin ecclesiastice confuse the three women, Uary, sister of Lazarus, Mary Magdalene and the woman who was a sinner, the additi on of the Bamaritan woman to the list was an exror peculfar to the ballads. It is not within the provinoe of the present discussion to try to distinguish these characters, but one may consider naturali. and excusable a confusi on of these women in the minds of the common folk, whose knowledge of the Bible was obtained largely by ear, and from priests whose scholarship was, in many cases, doubtful.

* *Fng. and scot. Ballads, p. 39. 
Carols.

Two examples of Carols are given in Mr. Kittredge's collection, "The Cherry Tree carol" and "The Carnal and the crane." Both are built on material from the highly popular book, the Paoudo Gospels of Matthew, the source of many of the medieval stories of the Infant Chriet and his contemporartes. The book abounde in martele and miracles and owos its origin and continuance to the popular lore of the marvelous, which its pretended sacred character sanotions. This amazing book contains the account of the Immaculate conception of Yary and the uni on of Mary with Joseph. The miraculous power the Infant Christ in inctructing his father Joseph and in compolling all things animate and inanimate to bow to hi. will have froquently been made the bubjects of early. art and 11terature.

According to Mr. Duncan's "Story of the Carol," the carol as a form of mualc was used in the Church in very early timea." "The carol," says Mr. Duncan, "is the celobration of a particular event in song." The Woel, of course, was one of the earliest and most popular of the carol subjeots; but carols were numerous and much enjoyed even as early as the sixth century, when Austyn is supposed to have introduced them in to England

* The Story of the Carol, Bdmondstowe Duncan, Scribners' sons, 1911. See page 3. 
in the elaborate music service of the Church which he encouraged.* Only one carol of Inglish composition before the conquest has been found, a manusoript of probeble ninth century origin, preserved in a Benedictine monastery in Cornwall.

\section{The Cherry Tree Carol.}

The older of the two carole in the baliad collection, "The Cherry Tree Carol," Ho. 54, tells a story of Joseph's roughly refusing to pluck a cherry for Hary, at which the unborn Infant cries out, combinding the tree to bow dow for his mother's convenience, so that she can obtain the fruit. Yr. Baring Gould says that this incident is the lingering of a very old tradition common to the whole race of man, that the eating of the fruit of Eden was the cause of the descendant of Eve becoming the mother of Him who was to wipe away that old transgresel on," *

The other incidenta in the carol, the predictIons made by the newly born child of his death and resurrection are added to gire a scriptural touch, and are "probably founded on the angel's words to the shepherds in Iuke II, and on Jesus' prediction in the authentic Gospels." - Mr. Kittredge. They may, howerer, have been taken directly from the Apocrypha, which says: "Jesus even from the cradie said to his mother, 'Mary, I am Jesus the son of God.' in

* The Story of the catol, Duncan, p. 29. *Ibid. . P.122. 
The carol bears out the tendency of the Apocrypha to disparage Joeeph. His attitude toward Mary is contempituous until after the miracie, when he expresses remorse. The 1dea seems to be that the holy nature of Yary and Christ are emphasized by contrast wi th the pureIy mundane character of Joseph.

The carnal and the crane.

No. 55, "The Carnal and the Crane," has a significance as being the nearest approach in the ballad collection to the very popular form of 11 terature called the "Beast Fable," which had its rogue from Anglo-Saxon days to the time of Pontaing as 11 terary material, and which, eren now, is rerired periodically. * The older forms followed the Phisiologi, a syle of literature anc cribing the properties, or "natures" of persons, pertieularly of Sorlptural obaracter or those connected with religious toachings, to rarious animals. The Phisiologi are said to have had their origin "in a religious document that arose among the Chriatians of Alexandria In the second century." * Copies and translations were opread throughout Burope and reached Ingland at an early date, "The carnal and the crane" retains littlo of the early popular nature of the beast fable, and is a remnant only in the fact of the carnal's, or Crow's, hav* Jusserand's Ite HLath of Jna People, p.76.

* schorield's Hist of sne Ifit., p.335. 
ing his well establishod character of wisdom, and in his thetructing the ignorant crane in sacred history.

According to $\mathbf{M r}$. Kittredge, *al though the present fort of the carol is of elghteenth century origin, the internal oridence points to much oarlier date. There is reason to suppose that this carol, l1ke many of the ballads, was long in circulation before it was commit ted to witing. This form of narration was extremely popular for sereral centuries, and 1 ts use of apocryphal material may be taken as a algn of early composition in one form or another.

The points taken up in the story are derired from the same apocryphal gospel that was the source of -The morry Tree Carol," and concern the nativity of yary and Christ, the lowly birth of Jesus, the star and the wise men's vilt, Herod's wath, connected with the testjmony; of the roasted oock, Herod's slaughter of the children and his pursuit of the Holy Family into Bgypt. In the course of the pursuit occurs the adoration of the beast and the miracle of the accelerated harvest, the main incidents in the carol.

The harrest miracle is a farorite subject for popular poetry for the reason that it has ouffictent sequence to form the basis of a good story. The Holy Family, in their flight, come upon a hubbandman sowing *KI ttredge' Eng. and Bcot. Ballads, preface to No.55. 
his grain. The Infant Jesus commands him to fetch his wagon to carry off the ripened grain, and sure enough, the harvest 1 miraculously ripened. The Child then instructs the farmer to answer the inguirieg of their purvuer by telling thom that Jesus had passed while he was sowing his grain. Herod and his tragin are thus decelvedand the capture of the Infant is arerted. The incident of the testimony of the roasted cock is the same as that given in the ballad "St. Steren and Herod." The cock, known as a sacred bird in many legends, has a place in the Zend Avesta of the fourth contury. An old wood-cut on a sheet of carols gives the scene in the stable at Bethlehem in which the various barnyard animals are opeaking, and the cock 18 represented as saying"Chrietus natus est," as in the baflad of $\mathrm{Bt}$. steren and Herod."*steron, howerer, has no part in the carol which follows the Apocryphal author: carefully.

* Duncan's stery of the carol, pp. 64,65 . 
Dives and Lazarus.

The ballad of "DIves and Lazarus"does not show eridence of great age. It is not known when the word Dives came to be used in Ingland as the name of the person in the parable. This name was used by Chaucor and in Plers Plorman; but the traditional namo was Hineueis.* The ballad is built directly on the Bible narration, Iuke XVI, 19-24, but 1s slightly altered in the detalls. In the ballad, Dires sends his servants to whip the beggar away from the gated, but the whtpe fall from their hands; the dogs are sent to bite him, but, instoad, fall to llokigg hls oores.' At Lazarus' death two angel carry him to hearen where he is to sit on an angel's knoe, instead of resting in Abrahem's bosom, as the original has it. When Dives dies, the ballad gives him two serponts to guide him to holl, whence he looks up and sees. Inzarus' bliss and asks in vain for a drop of wator.

Although the ballads are strong in the matter of miracles, they fail in impressireness. Like "The Maid and the Palner," the ballad of "Dires and Lazarug" cannot attain to the heights of the Bible account, Iuke 25-31, in whioh Direal repentence is so wonderfully portrayed. The ballad Dives bewails the terrible lim1treamness of eternity, and bemoans the fact that he cannot return to earth and re-11ve his $11 f 0$.

* Bmith' Dictionary of the B1b10, yol. II, p. 1618. 
The Vandering Jow.

The ballad of "The Wandering Jew" is not included in Mr. Rittredge's edition, but is contained in Vol. VIll of Yr. Child's and comes originally from the Peros collection. It is in ballad meter but in eight lined tanzas.

The first montion of the wandering Jow in Bngliah is found in the Chronioles of the Abbey of Bt. Albans, copled and continued by uatthew Paris, 1228.* A violting Armentan bishop tello the sory of the vandering Jew to a member of the monastery, affirming the existence of the man Cartaphllus, baptized "Joseph" by Ananias, who baptized Paul. Cartaphllus, he sald, was the door-keoper in the judgment hall of Pilate. He is said to have struck Jesus as He was passing, crying,"Get on faster, Jesus:" Thereupon the Man of Sorrows replied, "Iam going, but tarry thou till I come (again): This man lived on, haring his youth renewed erery hundred years, always returning to the age of thirty, his age at the time of Christ's death.

This story was widely ciroulated, and was incorporated Into PhIllippe Mouskes'rhymed chronicle. The Wandering Jow is said to have re-pppegred in the sixteenth century at Hamburg, calling himself Ahasuerus, formerly a shoemaker at Joruealem. Mr. Child states that *Bee The Cathollc Bhcyclopedia,vol. 1X,p.126 ff. 
50

the ballad was founded upon om e narrative of this event. Mr. Duncan in his Story of the Carols publishes an old carol called "The Wandering Jew."*

It seems strange, considering the interest and prevalence of the story, that no early popular ballad was originated on the subject; but perhaps the material is too subjective to yield to the ordinary ballad treatment.

* Story of the aral, Edmond tune Duncan. 
Ballade on old Testament Subjects.

Mr. Oblid Include in the elghth and last rolume of his work two out of the numeroue later ballade on Old Testament subjects, "Jophtha, Judge of Israel, "p,198, and "Bamson,"p.201. The ballade are of individual composition, following the B1ble accounte very accurately, and having no pretence to popular origin. $\mathrm{Mr}$. Child reforebto eereral ballads of oqual worth, among them, "The Constancy of Busannah," of ted in "Twelfth Night."

The balled of Jephthe is doubtless the one quoted by Henlet, Act II, s0. 11 .

Ham. "O Jeph tha, judge of I ereol, That a treasure hadet thou: "

Poloni us. "Whet treasure had he, my lord?"

Haw. "Thy-

One fair daughter, and no more, The which he lored passing weli."

and later:

Ham. "As by lot, God wot, It came to pass, as most like it was!"

The flrst stanza of the ballad reads:

- Ihave read that many years ago, When Jephtha, judge of I srael, Hed one falr daughter and no moe, find by lot, 080 wot. It came to pass, most like it was, Great wars there should be, And who ohould be the chief but he, but he." This ballad is known to have existed in the first half of the sixteenth century, and is probably of not much earlier origin. 
Bonnie Annie.

The only genuinely old ballad given by Mr. Kittredge, which may have been founded on an incident related in the 01d Testament,18 "Bonnie Annie," No.24. This quaint and touching bellad tell the tory of a young woman who fllos with her lover to Ireland, taking with her treasures and gold stolen from her parents. The royage is unlucky; the ship refuses to obey the rudder in the heavy storm, and the crew suepeot that a wicked person 1s on board. Ilke the otory of Jonah, they cast lots "twice six and forty times," to see which 18 the guilty person, and Invariably the black bullet fall. to Annie. She herself, then, overcome by remorse, asks to be trrom into the sea to save the others, The lover, constrained to agree, throws her overboard and follows her body, whioh floats before the ship to the coast of Ireland. There he buries her in a gold coffin made from the stolen treasure.

Although there is no reference made to Jonah, the idea of the ballad so closely resembles the Blble incident that one may suppose a connection. On the other hand, both tories may hare a like foundation in the common superstition among sellors that an eril or unlucky person on board ahip 10 the cause of a bad royage. 
Hatred of the Jews.

The religious side of the life in the daye on the ballade comes to the surface in another class of ballads in which the popular hatred toward the Jews is expressed. Ir. Kittredge's edition gives but one of these, Ho.155, "sir Hugh, or the Jew's Daughter," but he refere to twenty-one verelone of the eame ballad, which deals with the persecution of Christians by Jows. Mr. Child' collection gives two ballads, "Gernutus, the Jew of Venice," and "The Northern Lord and the Cruel Jew," both founded on the subject of the cruelty of Jewlsh usurers. The first,"Sir Hugh, or the Jew's Daughter, is old and typical of dit period, but the two latter are of more recent origin.

The Jews came to Ingland after the conquest In search of plunder and the frults of such disturbance as the new regime must, for a time, provoke. They were the bankers and merchants of exchange for Burope, and they alone were allowed to practice usury. On the other hand, they were confined in Jowribe, not subject to the law of the land, but directly reoponsible to the king, mere chattels at his absolute disposal.* The Iorman kings found the Jews their most useful subjects when it came to a matter of Iinancing a war, and, up to the time *Green's History of the English People, Chap. II 
of Edward I, they protected the Jews against the popular hatred. The antipathy of the people toward the Jews on: avcount of the difference of race, religion, and political status, was aggravated by the attitude of the Jews themselves, whose arrogance grew with their increasing wealth. Comparatirely secure in the protection afforded by the king, the Jews allowdd themselves to show their contempt for the ignorance and superstition prevalling about them, even jeering at the rellgious processions which passed their gates. Riots and massacres of the Jews became more and more frequent. The Jews were ace cused of perpetrating horrible crimes against the christ1ans, notably crucifying Christian boys for their blood, which was said to be a necessary part of the Paschal rites. This outrageous charge, so contrary to the character of the Jewioh religion, is first recorded in. 1144, given in the Ang10-8axon Chronicle as 1137, when William of Horwloh is sald to have been crucified by the Jews. Various simllar stories are told in the following hundred years and more.

Outbreaks against the Jows increased in vioIence; In spite of the protection afforded them by the king s, and the support given them by the friars, who, in some places, established their convent houses in the Jowries to assist them.* The Church must, in the main, *Green's Hist. of Ing. People, Chap. IV. 
be exonerated from the suspicion of having instigated or encouraged these riots. On the contrary, the records show. that the influence of the Church was of ten exerted to save the Jews from persecution, and to suppress accusations of murdering children and poisoning wells that the populace brought against them. Whatever impulse the Church gare to the natural fanaticlsm of the peoplo was probably from the lower ranks of the priesthood, where ignorance and superstition had 1 to strongest oothold.

The ballad, "Sir Hugh, or the Jew' Daughter," is founded on an occurrence in 1255 or 1256, which is recorded in T66 Annals of Vaverly, of Burton, and in Matthew Paris' Chronicle. The three stories agree in the main points, which comprise the following:*

A boy, Hugh of IIncoln, was said to have been tortured and crucified by the Jews in contempt of Christ. The tream into which the dead body was thrown refused to receire it and restored it to the bank. The body was then buried, but was cast up by the earth. It was then thrown into a well, but the brilliant light and sweet odor that emerged made known its presence and apprised ereyt ofie a infracle. Upon investigation the body was found floating on the water. When. It was drawn up, wounds on the hands and feet showed that the. *See K1 ttredge's Eng. and Scot. Ballads, p. 368. 
death had been through crucifixion, and the murder was ascribed to the Jews. Many miracles were performed by the body, such as restoring sight, etc. Eighteen Jews, convicted of the crime and confessing it with their own mouths, were hanged. Trail's social Ingland, note,p.287, gives an account in wich the statement is made that one hundred and two Jews were brought, in 1256, from Iincoln to winchester, charged whth having crucifled a Christian child. Eighteen were hanged and the remainder lay long in prison.

The ballad gives a somewhat different account, perhaps confused with some other reported crime, such as that on wich Chaucer's Priorese! Tale is founded. There is no point made in the ballad of a reason for the murder, and crucifixion does not enter into the story.

A boy, playing ball with his comrades, knocks the ball into a Jow's window. Seeing the Jew's daughter at the window, the boy, Hugh, asks her to toss it down. to him. She refuses, and entices Hugh into the house by offering him a red and green apple. When he yields, she leads him to a table where ahe murders him by stlckivg a knife into him. Haring wrapped the body in a sheet of lead, she throws it into the well, fifty fathoms deep. When, at evening, the other boys come home from school, Hugh's mother becomes anxious at the non-arrival of her son, and vets out to find him. After a search she comes 
to the well and calls aloud for Hugh. The boy's volce answe from below, telling his mother to prepare his winding sheet. The next morning the ghost of. Hugh comes for his burial, which is celobrated with miraculous ringing of bells and reading of books.

The prevalence of such stories gave rise to a belief in a number of boy martyro, and Saint Hugh. was "canonized by popular reverence." Host historians agree in estimating these stories as pure fabtications, forming a disgraceful chapter in the history of England. The persecution of the Jewr eventually led up to their summary expulsion in 1290, when sixteen thousand Jews were sent out of the country.

\section{"Gernutus " and "The Northern Lord and the Cruel Jow."}

The ballads of "Gernutus" and "The Northern Lord and the cruel Jew" contain, in part, the same mater1al. The Jew story of "The Merchant of Venice" with which Shakespere has made us familiar forms the basis of both stories. Mr. Child states that, al though the story of the cruel usurer is of oriental origin, the earlieat European forms were in the Gesta Romanorum and in an Italian and a French manuscript of the fourteenth century. There is no reason to suppose that *Green's Hist. of Fnge People, Chap. IV. 
there was an Bnglish ballad of much earlier composition than this comparatively late one, which may or may not have preceded Shakespere's play. There must have been a close connection between shakespere' "Merchant of Venice" and "Gernutus", or both must have been derived from the same source.

The second ballad is a strange mixture of stories, one of which resembles the story of "Cymbeline." The wager, the stealing of the ring, the supposed death of the wife and her re-appearance disguised as a youth, bear out the 11keness. Shakespere's "Yerchant of Venloe". is suggested, not only by the Jewish usurer story, but also by the incident of the rescue of the knight from the usurer's clutches through the wiodom of a bystander. who turns out to be the wronged and much regretted wife. Wi thout evidence to the contrary, I should judge the ballad of "The Northern Lord and the Cruel Jew" to be a later and much garbled rersi on of Shakespere's two plays, turned into popular rhyme. 
Other Religious Iaterial.

The main groups of ballads that contain evidences of the Christian faith have been considered. There femains, however, scattered throughout the collectIon, a limited quantity of Biblical and religious material that may be treated under falrly distinct headings:

(a) Ballads containing mention of various Church officials.

(b) Riddles containing religious material.

(c) Ballads presenting the custom of church rites in burials, weddings and other sacrements.

(d) Miraculous interventions of the virgin or of Christ.

(e) Ballads showing a confusion of heathen and Christian superstition.

The frequency of oaths that owe their origin to the Christian religion needs not be considered serLously, as such expressions, used mainly as expletives, could have been inserted at any period in the $11 f e$ of the ballad. The same is true with regard to the dating of an event by a Church day of celebration, such as Martinmse or Christmas. The Yule season is mentioned in the same way and has no olgniflcance in placing the ballad. 
Church Officials.

The ballade contain mention of the more common Church officials, mainly bishops, priests, and an occasi onal abbot. Few of there persons, however, are necessary to the plot of the story. In those which include church ceremonies, a priest, sometimes called a mass priest, is required." King John and the Bishop" No. 45, which is treated in this artiole under the head of Riddle Ballads, is founded upon the intercourse of

a king and a bishop. It is not essential to the story that the characters should be a king and a bishop; but the exalted titles are doubtless for the purpose of lending dignity and importance to the story.

$$
\text { No. 156, "Queen Bleanor's Confesel on," is }
$$

based upon the story of a false wife, called queen Hileanor, who sends to her native France for two friars to. hear her confession. Her husband, named King Henry, learning of her intention, disguises himself and a courtier,Barl yartial, as two friars, and thus hears his wife's confessi on of her misdeeds. The fact of the confession to two friars is a point of interest. Mr. Kittredge's note on this matter in his introduction to this ballad says:

"This ballad seems first to have got in to print in the latter part of the serenteenth century, 
but was no doubt circulating prally some time before that, for it is in the truly popular tone. The fact that two friars hear the confesel on would militate against a much earlier date."

Palmers come into the ballad otories in sereral instances: in 10.21 , treated in this article under the head of Bible stories; in Io. 30 , in which King Arthur and his knights use the palmes's dress as a disgiso; in No.114, in which men ask an old palmer for news; and in No.226, which taker up one of the solomon stories, but in so degraded a form as hardly to be recognizable, and in which the husband effects a disguise by using a palmer's dress.

The comparative frequency of the mention of palmers is almost the only $81 \mathrm{gm}$ in this literature of the crusading movement, with the exception of "old Robln of Portingale," Ho.80. In this ballad the hubband, after punishing his wife for hir unfai thfulness, places the white and red cross on his shoulder,

"And he went him into the Holy Land, Wheras Christ was quicke and dead."

mile palmers are met with often, they are not referred to with the degree of reverence that one might expect, but are usually spoken of as "old" and of no Importance. Palmers, were, as a rule, men self-condemned to poverty and to continual wandering from one shrine to 
another until death. The custom did not have its beginning in the great crusading movement, but was known some conturies before. Mr. Bidney Heath tates that "during the tenth and eleventh centuries men were somotimes ordered to become palmers as a penance for their sins." * Their name was acquired from their custom of weering palm branches or emblems of palm leaves brought from the Holy land. One surmises that the custom of holy mendicancy, such as palmers and friars maintained, soon lost Its appeal to the people who were called upon to support ito rotaries.

R1ddies.

The ballads present a favorite mode of diversi on among the Anglo-8axons and their successors in several series of riddles, of-which a few are included in the collection of Mr. K1ttredge. These show el ther Christian origin, or, what is more probable, the inser -...i. tion of a few verses of Christian material in an old series, or the adaptation of an ancient riddle series to a more modern story and setting.

In so.1, there are two verses of plainly

Christian origin;

(8) "What 1 s better than the bread?"

wi th 1 to answer;

* Lr. Bidney Heath's Pilgrim life in the Yiddle Ages, p.99. Hough ton, IIIIIIn Company, Doston 1912. 
(18) "God's flesh is better than is the bread." and-

(10) "What is richer than is the king?"

answered by-

(20) "Jesus is richer than is the king."

Later versions of the same series give different riddles on Chriatian subjects.

No.45, "The King and the Bithop," is an example of the adaptation of a very old series in which a man must answer three hard questions correctly or ouffer a severe and quite disproportional penalty. No.47 1. adapted to a Chriatian audience by the addition of the Idea that the riddles propounded by the haughty lady are answered by her brother, who has returned from the grave for the purpose of teaching his sister the Christlan virtue of humility.*

Church Ri tes.

As a development similar to that of the riddles one may consider the many verses and stanzas in the ballads which relate to Church rites. These, in many cases, bear evidence of being stereotyped forms that have been added by the later balladist or scribe. stanzas narrating churchyard burials are a farorite form of closing affecting stories in which one or both lovers meet

* For Angl 0-8exon Riddles, see Jusserand's Hist. of Bng. I1t., p.. 72, note 2 . 
death. Such endings, which show the childlike desire of simple folk to bring the tory to 1 ts full conclusion, a are found in Nos, $7,64,74,75,76,85$, and $87 . \mathrm{A}$ few Iines from No.7 will serve as an example of these stan288:

"Lord William was buried in Baint Mary's kirk, Lady Margaret in Mary's cholr;

out of the lady's grave grew a bonny red rose, And out of the knight's a briar."

Church marriages, burials, christenings, and the regular mass are frequent in the ballads, but form an essential part of but fer; notably of 10.41 , in which the children of an unequal uni on - probably the remnant of one of the numerous old faity and mortal stories are desirous of being christened with the full rites of the Church. The Iorse and German versions of the ballad, to which Mr. Kittredge refors, have also this idea of Christian ceremonial, but much confused with the heathen figures of elres and dwarfs. the softentrig influence of. Christianity is observable in the change which this story has undergane, for, in the older dwarf stories, the breaking of the spell by pronouncing the name of the lover is followed by immdiate disaster to the woman, but in the Christian rersion, the naming of the lover, followed by the proper ceremonies at the church, restores the husband to his family, and all onds happliy.

* Kittredge's Bag, and scot. Ballads, p. 70, 
Nos.. 49 and 77 mention burial in the churchyard; Nos.48 and 73 speak of marriage at the church door, and in No. 63, Child Waters promises a bridal and churching on the same day. In 10.49 , the dying brother request that his Bible be lal at his head and his chaunter at his seet.

A varlation of these stories is found in $\$ 0.96$ in which a woman, in order to aroid marriage with one whom she does not love, feigns that she is dying, and as a parting request, begs that her body be carried past three Scots lirks with the customary ringing of bello and chanting. It is prosumed that she is to be buried at the fourth church. Her brothers carry out the dying prayer of their sioter; but at the third kirk the girl'o true lover, hearing the bells, approaches the bier, and recognizes his sweetheart. At once the gitl returme to consciousness, and the lovers are united.

A similar instance of a sham death is told in \$0. 25 , in which the lover thus succeeds in winning his bride.

Miracles of the Virgin and Christ. No. 57, "Brown Robin's Confessi on," is worthy of opecial attention from ite significance as having a. touch of the Jonah story and being the only ballad extant that deals with a direct miracle of the virgin. The subject of the cult of the virgin is treated in this article under the head of "Robin Hood Ballads," and the 
story of Jonah is discussed with the old Iestament storifes, but this apparent combination of the two stories is uni que.

The crew of a ship which has met with rough weather cant "kevelo" to discover which is the evil pero son who is causing the 111 luck. The lot falls to Brown Robin, who, truck with remorse, confesses two crimes, and offers no resistance to being thrown in to the sea. Tied to "plank of mood," he is thrown into the sea and left, to his fate. His straightforward confession of his evil deeds has meanwhile gained him the favor of the Virgin Mary, who, coming by with her "dear son," takes Robin with her to the High Heaven.* 1

$$
\text { \$o.' 59,"Sir Aldingar," is also of unusual }
$$

importance. In Mr. Kittredge's note to this ballad, he says that william of Malmsbury, undoubtedly following ballad authority, tells a olmllar story of the emperor Henry III and Gunhild, daughter of Cnut and Emma. In the ballad of Sir Aldingar; the queen, condemned to the flames for infidelity on the false testimony of the stewaed, is saved by the intervention of a ronderful child, who overcomes the false steward in the combat. This child, who appears to be about four years old, presents a confusion of the elf idea with that of the Christ Child in the Apocryphal stories of the Infant Jesus' miraculous achievements. 2

2 * See No. 29, Bng. and Bcot. Bopular Ballad for an example of the "ronderful child."

1* See Bonnie Annie, Io. 24, and A Gest of Robin Hood, No. I17, Fourth Fytte, Eng. And scot. Ballads. 
Confusi on of Heathen and Christian Superstition.

Perhaps the most interesting phase of the religi ous element in the ballads is the intermingling of heathen and christian beliefs and ouperstitions. The fact that some of the ancient superstitious beliefs and practices have persieted to this day, in the distrust of an undertaking begun on Friday, and the half playful following out of hallowe'on rites, besides innumerable customs of lesser Importance, shows the strength of the fal th in it beginning and the place it must have held in the early life of the race.

It would be impossible to innumerate every instance of this confusi on in the earlier ballads. only a few of the most important examples can be touched upon. In the ballad last quoted, sir Aldingar, No. 59, the nature of the marrelous child is partly that of Christ and partly that of an elf. The sword he wields. emi ts a wonderful light, which the ballad explains is caused by 1 ts gilded surface. This is plainly a corruption of the magic sword idea of the old stories, as in rŏ. 60 , where the swords are enabled to bite sorely "Through the help of gramarye," or magic. No.4, "Lady Isabelle and the Elf-Knight," is, in 1 ts earlier verolons, a pure fairy story, but in the "H" rergl on given by $\mathrm{H}^{\prime}$. Kittredge, the elf-knight lover 
has become a priest, in either case having a more than ordinary character. The lover of the still later veralons is a mere False Sir John, whose Blue-Beard propensity for killing his wires finally meets its proper punishment. The substitution of a priest for the elfknight leads to the question of whe period at which celibacy among the priesthood was established. The fact that the priest's woolng, in the ballad, was unusual and forbldden is evident. Although the celibacy of the clergy was enjolned in the third century and thence on, and even commanded by sucessive popes, it was not enforced with vigor until the time of Gregory VII, whose decrees in 1074 positively forbade the ordination of a married priest.

All the superstition of heathendom, an eif, a magic horn, a bewttched horse, and a magic sword enter. into the ballad of "Arthur and Xing Cornwall," No.30. In the midet of this magic is placed a bit of barly Christian superstition in the miraculous power of a Holy Book, which Mr. Kittredge suggests is the book of the Evangels. In the story, Arthur and his knights, undertaking an expedition against King Cornwall, assume the di gguise of palmers, make their vows to the Holy Trinity, and depend for protection upon a little book which the Iord had written with his ow hands and sealed with his blood.

This curious jumble of superstition may have 
arisen as early as the twelfth century. Arthurian romance and the idea of chiralrous love had their growth in France and were not planted in Bngland until the late eleventh or early twelfth century. The ballad itself, according to 1 to form and style, is judged to be of comparatively late composition.

\section{similar minglings of elf and falry lore and} Christian ideas are met wi th all through the older bal1ads. One may note particularly Yo.39, "Thomas Rhymer," it In which Thomas mistakes the elfin queen for the queen of Heaven. The elf queen adde to the confusion by pointing out to Thomas the roads to hearen and hell.

In No.39 the wi tchery of Hallowe'en and the 4 : efficacy of christening as a protection against evil or the elfin spell appear side by side. No. 4l, in which christohing remores the ban from the elf knight is a similar story. In 10.34 a spell is not to be removed until St.Mungo comes brer the Bea. No. 40, a fragment, contains the story of the fairies' spiriting away the mother of a young child to obtain a nurse for their own fairy children. The mother mourns for her babe and for Christendom, and seems to have a $\nabla 181$ on of the roads to hearen and hell. 
cONCLUSI ON.

No ballads have been discussed in this artiole which concern historical eventsiof known date. A few have been studied that contain mention of erents of which the approximate date can be ascertained by references in the ballad to historical matter, such as those connected wi th the Jews. Apart from these, and from the ballads dealing with Bible stories, or based on essentially Church material, making in all but a small group, the ballad material, as a mass, may be regarded as traditional from a very remote past.

The comparatively small quantity of Christian or Bible material in the ballads may be due to two, or possiblg more, causes. The origin of the balladr may antedate the spread of Christian faith among the reutonic people; or, religious subjects may not lend themselves to ballad composition Bo readily as they do to a longer and more sustained style of poetry, and to prose. The very nature of the ballad demands complete familiarity with the subject, and the condition of being at ease, and free to tell in simple and accustomed phrase a story without complication of 1 deas or events.

The ballads deal with the fundamental emotions of men and women, their love and hate, their domestic 
Iife, their social and rece customs. Many are pervaded by the fear of the mysterious, unknown shadow world of the supernatural. The evidence of the transition from the old forms of religi on to the new faith, a process so slow that eren now it is not yet fully accomplished, constitutes one of the chief charms of these ballads. The student feels himself transported back to the childhood of the race as he reads these simple yet vivid; pictures of the life of the people.

The ballads teach no lesson. Eren in the later groups there is no tendency to moralize after the style of the homilists. There is no striving after effect, no attempt at allegory, and no evidence, throughout this il terature, of an ulterior motive in the teliling. In a verse suited by 1 to eimpliolty to the nature of 1 to subjects, all the strength, the unrestrained emotions, the . love of the glittering and the marvelous that character1 ze a young race find their expression. 